Reading Between the Lines: Librarians as Authors of Fiction

Julie Still

Reference Librarian

Paul Robeson Library

Rutgers University

Paul Robeson Library

300 N. $4^{\text {th }}$ St.

Camden, NJ 08102

$856225-2846$

$856225-6428$ (fax)

still@,camden.rutgers.edu 
Reading Between the Lines: Librarians as Authors of Fiction

The image of librarians in fiction and the media has been widely discussed in the professional literature, but librarians as authors of fiction has not, beyond news items of specific authors. Since beginning writers are encouraged to write what they know, it is not surprising that some librarian novelists create librarian characters or library-themed plots. This article reviews librarians as authors generally and examines the works of two librarian novelists, Miriam Grace Monfredo and Jayne Ann Krentz in detail. Both present library related issues. The possible use of well-written fiction that provides an interesting and accurate representation of information gathering and evaluation is discussed, as are other possible research topics in this area. 
Reading Between the Lines: Librarians as Authors of Fiction

Note: This article is based in part on a conference paper presented at the Popular Culture Association and American Culture Association Joint Annual Meeting, Philadelphia 4/12/01. The paper was not included in the proceedings or distributed at the meeting.

Librarians and other scholars have studied the representation of librarians in fictional narratives and media, such a film and television: notable examples of these studies are Burns (1998), Frylinck (1990), King, (1990), and Chaintreau (1990). This is also an especially popular thesis topic (Cavanaugh, 1976; Long, 1957; Nation, 1956). However, there is considerably less study of librarians as the authors of fiction. This paper will examine the fiction of librarian writers, and how, or if, their background in librarianship might influence their work. The focus is on American authors, and on librarians who became writers, not those who went to library work after finding success as an author. Certainly there are many librarian authors outside the United States -- for example, New Zealand's Daphne Clair and Germany's Gunter De Bruyn, who worked as a librarian for several years. In Britain, the editor of Black Lace books, a series of erotic fiction titles, claims that two of the 18 writers for the imprint, are librarians ("Novel," 1994, September). And there are authors who decided to start a career in librarianship, either to augment their writing, or just because they enjoyed the work. Among other American authors, Ruth Moose worked as a free lance and short story writer for many years before getting an MLS and taking a librarian position; Peter Sieruta is also published writer who works in a library, and Lois Walker, who writes under pseudonyms, worked as a full time writer for years before going back to school for an MLS (Chepesiuk, 1991). Some are difficult to categorize. Arna Bontemps had 
been writing books for many years, including the acclaimed Black Thunder, before receiving an MLS and taking a library job. He continued to write after that, but his writing style and habits had probably been set before coming to librarianship.

\section{SCOPE AND METHODOLOGY}

The scope of this paper is limited to writers of adult fiction, although there are also librarians such as Pat Brisson, Caroline Feller Bauer, and Avi, who write children's literature. Russell Chenowith, who retired from the Van Pelt Library at the University of Pennsylvania, wrote a book that was classified as juvenile fiction although he thought it would be of equal interest to adults.

The double role of librarian and fiction writer is not a new phenomenon. As we all may be aware, Casanova is rumored to have been a librarian. Mary Laram Knight McConnell was a World War II war correspondent during World War II who earned an MLS in 1968. She rewrote her MLS thesis and published it as The Fox that Wanted Nine Golden Tails, a children's story. Perhaps one of the most respected and best known American librarian authors is Dee Brown, who wrote Bury My Heart at Wounded Knee and Creek Mary's Blood. He worked as librarian for 40 years, 25 of them at the University of Illinois. One of the most prolific librarian authors, although her library connection is not that well known, is noted science fiction writer Andre Norton who worked as a children's librarian at the Cleveland Public Library for 20 years before becoming a full time writer.

Finding out the previous or current "day job" of writers is not an easy task. Some of the authors listed here are ones I know to be librarians from the blurbs in their books; some I found while searching through the library literature. However, other than one article in the November, 1991, issue of 
American Libraries by Chepesiuk, there does not seem to have been any research presented on librarians as novelists. Searching for "librarian" as a text word in the online version of Contemporary Authors, part of Gale's Literature Resource Center database, retrieves over 4,000 entries (information not otherwise cited was found through this source). Many of these are for writers who had a librarian parent or spouse; an equally large number are for entries with School Librarian or a similar title in the bibliography. Few are for librarians proper who also wrote. Of those, many wrote non-fiction, often bibliographical studies. Searching through other sources, such as Librarians in Fiction: A Critical Bibliography, by Grant Burns, scanning for novels that seem to present detailed or extremely realistic library scenes or librarian-themed works, and then tracking down information on those authors, or finding entries that clearly state the author was a librarian, is another tact. Anthologies, such as Dangerous Men and Adventurous Women, by Jayne Ann Krentz (herself a librarian) also provide sufficient author information to identify a few other librarian novelists.

What constitutes a librarian is another question. Thomas Berger, author of Little Big Man, served as a librarian at the Rand School of Social Science for three years before taking a job with the New York Times Index. Does this make him a librarian? No graduate degree in librarianship is mentioned, but at this time, around 1950, there were probably quite a few people identified as librarians who did not have a library degree. Does a short stint working in a library count? Does a mention of a brief stint as a photograph librarian constitute classification as a librarian? In this study, I adopted rather stringent guidelines and decided against including people who had tenuous connections with our chosen profession. So we are left with self-identification, and a careful sifting of career and education information. Another question that arises is what constitutes a novelist? Some librarians 
wrote several non-fiction or bibliographical works and one novel. Others wrote one novel and nothing else. Neil Boardman, who worked as a librarian for over 20 years, wrote two novels and several television scripts for "Alfred Hitchcock Presents." Would these individuals count as novelists? It is also sometimes hard to differentiate between a novel and what might be called a memoir. For earlier authors this type of information is hard to come by without actually handling or reading each text. In reviewing author information in this study I took time frame into account, knowing that in the past people without educational qualifications, for instance an MLS, were known and accepted as librarians. To circumvent this research difficulty, I looked primarily at writers in recent times who either identified themselves as librarians or had the educational qualifications we would want if hiring them today.

\section{LIBRARIANS AS AUTHORS}

Fledging writers are advised to "write what they know." This is why John Grisham, trained in the law, writes so much courtroom drama. And why Patricia Cornwell, author of the Kay Scarpetta thrillers, writes of forensic medicine, since she worked in a medical examiner's office. I don't know how to explain Stephen King. An example of a librarian novelist writing what is familiar, is mystery writer and former librarian Miriam Grace Monfredo, who has created a fictional historical detective in librarian Glynis Tryon. Her books are complete with descriptions of collection development problems, the profession as a stereotypic alternative to marriage, and the importance of the written record in property disputes and inheritance matters. She is writing what she knows. Once a writer is more comfortable with the writing process he or she may be more willing to expand into other areas. As seen in examples below, many librarian authors have librarians in their first or early works but branch out in later works. 
Elizabeth McCracken, a literary novelist and former public librarian, creates a librarian character in The Giant's House, which was selected as a Book-of-the-Month Club book and a finalist for the National Book Award. The librarian character does play to stereotype to some degree, being unmarried and with no family or friends. However, she changes this situation in the novel when she falls in love with a disabled man 15 years her junior. McCracken has also written short stories with librarians as characters. She is writing what she knows (Dowling, 2001).

Eleanor Cameron worked as a librarian for many years. While she wrote at least two series for young adults, her first published novel, The Unheard Music, has a librarian as the main character. Charles Goodrum, a librarian at the Library of Congress for roughly 30 years, wrote four librarythemed mysteries, Best Cellar, Carnage of the Realm, Dewey Decimated, and Slip of the Tong. Barbara Fister, a name familiar to those who read academic library publications, has written a mystery novel, On Edge, but chooses a Chicago policeman as the protagonist.

Romance novelist and former librarian Jayne Ann Krentz, who has a BA in history, as well as an MLS, has created fictional librarians but a more pervasive theme in her works is the importance of information, information gathering and information use. For example, in her 2005 novel Wait Until Midnight (written under the pseudonym Amanda Quick), the hero made his fortune as a sort of information broker. He paid prostitutes to tell him the financial and social secrets they learned from their clients and then he sold the information to others. The romance genre does seem to be the most popular place to find both writers who have kept their day job as librarians, and full-time writers who used to be working librarians. Cathy Linz is another former librarian / romance writer, with more than 30 titles to her credit. Before leaving to write full time she was the head of acquisitions at 
Northern Illinois University Law Library. Sandra E. Kitt's entry in Contemporary Authors lists her membership in the American Library Association and well as the Special Library Association. She has held a variety of library positions, including manager of New York's Hayden Planetarium Library, and an 18 year stint as an information specialist. In addition to her numerous romance novels, she has written articles and reviews for museum and library journals. She has also created librarian characters, including the heroine of her recent She's the One (Poling, 2001).

In addition to Monfredo and Krentz, writing as Amanda Quick, mentioned above, other librarians, especially those with educational or work backgrounds in history, have found a second career writing historical romances or historical novels. Cynthia Whealler, who uses the pen name Evelyn Richardson, is another librarian romance novelist. Whealler has an MLS as well as an MA in $18^{\text {th }}$ century literature, a degree that comes in handy as her specialty is the regency romance, set between 1811 and 1820 (Chepesiuk, 1991). As another example, Shirley Frances Barker, who worked in the American history section of the New York Public Library, wrote historical novels.

\section{MIRIAM GRACE MONFREDO}

In this article I will focus on just two of the aforementioned authors, Miriam Grace Monfredo and Jayne Ann Krentz. Monfredo, as previously mentioned, writes historical mysteries. Although her entry in Gale's Literature Resource Center database does not refer to her work as a librarian, the biographical blurbs in her books note this fact. Glynis Tryon, the female lead detective in her early works, is a librarian in Seneca Falls, New York, during the early and mid 1800s. Later books introduce her nieces, one of whom is a spy, the other a nurse, and Tryon plays a lesser role in these titles.

One interesting aspect of her works is that unlike most series, 
mysteries included, the books take place over time and the characters age. The first in the series takes place in 1848, while the fifth takes place in 1860 , the year Abraham Lincoln was elected president of the United States. Several years elapse between the books. Like any good librarian, she likes to have a few pages of each work devoted to the sources used and the historical accuracy (or liberties taken) regarding the events in the book. She also tends to be very scrupulous about thanking those who assisted her, including fellow librarians.

She includes a variety of current (perennial?) library issues in her works. In the first book, Seneca Falls Inheritance, published in 1992, the thorny mixed blessing of gift books is a pivotal point in the action. A local resident has donated a box of books to her library, including a family Bible put in the box by mistake. The Bible is later stolen from the library, but then rediscovered. In it, the owner had recorded the birth of a child from a previous marriage, which would affect how his estate was distributed. The Bible's worth lay in its use as a legal document and source of family information. One passage on page 5 in particular about librarian Glynis Tryon resonates with anyone who has a cataloging backlog:

"It was a violent jerk of her neck muscles that brought her upright, recalling her to the remaining crates of Friedrich Steicher's books. They had not unpacked and catalogued themselves, had not arrived on the shelves by way of wishful thinking. They just lay there accusingly. She let out a sigh."

In the novel, Tryon is also concerned about the suitability of some of the works for the members of subscription library and how her board will respond: Jane Austen's novels and Charlotte Bronte's Jane Eyre are among those causing a stir. 
In North Star Conspiracy, which takes place some six years later, in 1854 , the focus is on the underground railroad. However, again, Monfredo includes literature contemporary with the time -- Uncle Tom's Cabin. Also discussed is the issue of who may use the library, and whether or not one or two of the characters are "subscribers" to the library.

The third book of the series, Blackwater Spirits, focuses on Indian / European relations. In this novel, Monfredo introduces Glynis's assistant, Jonathan Quant, who favors popular novels a little more than she would like. Unfortunately, Monfredo does not explain this unlikely staffing situation in which a male would serve as the assistant to a female librarian in pre-Civil War New York.

The fourth book, Through a Gold Eagle, opens with Glynis returning after a year's absence to care for an ill family member. She finds that Quant has opened the subscription library to the public, or, more specifically, that he has offered a half-price associate membership for use of the library two afternoons a week. Glynis responds with the following words on page 64, no doubt still echoed in administrative meetings everywhere:

"What I can see is that the Seneca Falls Library is being used for other than what its charter defines. Or have you, perchance, cleared this revolutionary plan of yours with the board of directors, who are, as you well know, the stockholders?" She herself is not opposed to the idea but thinks "more people meant more books, more periodicals, more newspapers - paid for by whom? How? The obstacle was - always had been -- money."

To make matters worse Monfredo discovers that Quant has been purchasing primarily romance novels to satisfy these new patrons, and, to make matters worse, depending upon a bequest from a still-contested will, to 
pay for it. Her assistant asks her on page 65 "Miss Tryon, if romantic novels are what people most want to read, why shouldn't we have more of them?" This is the "should we give them what they want or what they ought to have?" question that has plagued librarians from the very first acquisition. In later books, such as Must the Maiden Die, we find fewer discussions of library-related issues and see less of Tryon's library work. She does take children's books to a shelter, but there is no mention of their status. We don't know if they are loans or gifts or items she herself has purchased. The action has shifted to other matters and soon we will read less of Tryon herself and more of her nieces.

While Monfredo focuses on historical events, the day to day existence of her heroine is filled with the details and problems of practicing librarians everywhere. These mundane details could ruin the flow of her books or make them seem false if not written correctly. But Monfredo's library experience clearly come into play as she accurately portrays library routines. Since, as mentioned, the focus of her later books shifts more to the activities of Glynis Tryon's nieces, it may be that she used her library roots as a structure to build around until she was more comfortable with her writing skills, and able to venture further afield.

\section{JAYNE ANN KRENTZ}

Jayne Ann Krentz, using a variety of names, has over 120 books published, several of which have been on bestseller lists; she is perhaps the best known contemporary librarian author. While her works are classified as romances all of them also have an element of suspense. And they are, from this reader's viewpoint, quite good, especially her later works, those written after the early 1990's. In her early writing years she wrote for syndicates such as Harlequin, under pseudonyms and those books are now being re-released. Syndicate romances often have detailed guidelines for writers, 
which likely provided the structure she needed as a new writer and allowed her to be more independent of her experience. As of 2005, she uses three names. Under the name Jayne Ann Krentz she writes contemporary romances, under Amanda Quick she writes historical romances, and under Jayne Castle fantasy romances. Few of her books have librarian characters. One is Perfect Partners, wherein the female protagonist, Letitia Thornton, manages the reference desk at a small mid-Western college. Her life is drastically changed, however, when she inherits an outdoor equipment company from her uncle, just when her wedding engagement ends, so she moves to Seattle to take over the reins of the firm. When the CEO who had hoped to buy out the uncle in a year's time, questions her business experience she replies that she had read several books and articles on the subject. When her father questions her managerial experience she refers to her six years as head of reference and the supervisory duties it entailed.

Of course she is able to assist with the general direction of the company but it is through personal testing of the camping gear it markets, as well as cleverly rewriting the instruction booklets that go along with tents, etc., and astutely determining the best color for some of the women's jackets, that she most contributes to the company. And, yes, she and the CEO do fall in love and marry. Her father, stepmother, and the discarded former fiancé, the academics in the book, are all portrayed as well-meaning but out of touch. One of her earlier works that has been recently re-released, Private Eye, also concerns a former librarian who now runs an inn. It is interesting to note that she wrote both of these books in 1992, just as she was beginning to move away from writing for romance syndicates into more independent agreements with publishers.

While librarians per se do not appear often in Krentz's work, the importance of information and its use is a library-related theme that does 
recur. One of her female protagonists, Charlotte Arkendale in Affair, runs a business doing background checks on potential husbands for women who have some money and don't want to be swindled by fortune hunters.

When asked how she finds this information she replies "From many sources. Servants in the household or those employed in gaming hells and brothels supply some of the answers." (Krentz, 1998, p.176)

While the theme of information gathering, arrangement, and usage, is often subtly placed, Scandal, the first novel she wrote under the Amanda Quick pseudonym, could easily serve as a primer in information literacy. Take for example, the hero's statement from page 62, "Rest assured, my dear, I always try to fortify myself with as much information as possible before I set out on a project." While I, as a university librarian, have tried to impart this philosophy to students for decades, I fear it is likely that this hero -- Simon Augustus Traherne, Earl of Blade, he of golden eyes and powerfully built physique -- would get the message across much more clearly.

Later in the book (p. 233), he instructs his true love's younger brothers:

"Faringdon, it is time you and your brother learned that real power is based on money and information. Armed with those two things a man can accomplish a great deal more than he can with a dueling pistol or a deck of cards."

“And if a man lacks the blunt [money]?" Devlin asked shrewdly.

"Then he must concentrate on obtaining the information. With a sufficient amount of that resource, he will soon find the other."

Emily Faringdon, the object of his affections (also, in a plot twist, the tool of his revenge against her father), has a fondness for romantic poetry, 
but also an uncanny knack for making profitable investments. Unlike many fictional market whizzes, she does not rely on hunches or sheer genius, but keeps her nose to the grindstone. Although this passage, from pages 75-76, is lengthy it does identify her use and evaluation of varied information sources:

"Unenthusiastically Emily pulled the latest issue of The Gentleman's Magazine toward her and opened it to the monthly summary of stock exchange prices. She scanned the daily fluctuation in prices on canal bonds, India bonds, bank stock, and the funds, making a few quick notes to herself before turning the page.

Then she ran her fingertip down the summary of recent prices paid for wheat, rye, oats, and beans in the inland counties and compared them to the prices paid in maritime counties. Again she picked up her quill and jotted down a comment or two. Next she checked the average prices of flour, sugar, hay and straw for the proceeding month, looking for trends.

When she was finished noting recent prices on commodities, Emily turned to the monthly meteorological table. This she gave only a cursory glance. It was still winter and the daily temperatures and rainfall amounts were not as important to her calculations now as they would be in the spring and summer. In a couple of months she would begin watching them closely in an attempt to anticipate the harvests.

When she had finished gleaning what she could from The Gentleman's Magazine, she turned to her correspondence. Sir Alfred Chumley had news of a new coal mining enterprise and a certain Mrs. Middleton had written to inquire about Emily's interest in a ship that would be leaving soon from the West Indies. It was expected to return with a sizable profit, just as the last one had." 
Would that undergraduates approached their term paper research with the same diligence! The plot of the book, of course, involves the meeting, mating, and marrying of Simon and Emily, the growing sense of trust and love between them. Together they remove the obstacles to their joint happiness, which is described through explicit but tastefully written love scenes. Given that it is now accepted that any kind of reading, comic books, fictional series like the Nancy Drew and Harry Potter titles, improves students' reading skills, is it not also likely that anything that reinforces the importance of careful information gathering and evaluation would be helpful in showing students the importance of lifelong learning? Perhaps Scandal should be an optional reading for any credit course in library usage or information literacy. The centrality of information, its types and uses, is clearly threaded throughout the story. Emily helps set up pension schemes for the family servants as it is clear her spendthrift father cannot be expected to set aside any money for them. She also runs a de facto investment club for the ladies of the Thursday Afternoon Literary Society in Little Dippington, where she languished until Simon married her and took her to London. Her financial acumen is highly valued by her father and brothers who delight in spending as quickly as possible the money she makes.

Librarians seeking unique ways to introduce students to information seeking or retrieval skills and the concepts of lifelong learning and critical thinking could do worse than suggesting students read novels that present those skills and concepts in positive and effective ways. If students like to read romance novels, using one of those as a conversation starter or segue to information gathering for the task at hand is simply one more tool in a teacher's repertoire. For example, if a student has read Krentz's Scandal, ask that student to find out what resources a contemporary Emily would use to 
choose investments.

In contrast to Emily's use of information for financial investing, Simon, uses his information gathering skills to manipulate circumstances and people. Take for example this description of him on page 258: "He got that way [powerful] by ensuring that he always knows the deepest, darkest secrets of those with whom he deals. This information gives him power. And he does not hesitate to wield it." This gender difference in the uses of information is another theme that is evident in Krentz's books.

Krentz, as Amanda Quick, has written a series of three novels (Slightly Shady, Don't Look Back, and Late for the Wedding) that follow the adventures of Lavinia Lake and Tobias March, who have set up a forerunner of the modern detective agency. In these books as well the differing types of information available to men and women is indicated. As Mrs. Lake says on pages 14-15 of Don't Look Back, "A gentleman is free to make inquiries in certain places where a lady would not be welcomed, if you see what I mean."

A few other female characters dabble in the market or other scholarly pursuits. However, they usually do so for the betterment of their loved ones or as a social service. Although Charlotte Arkendale, in the novel Affair, runs a business she is by no means wealthy and is trying to help women avoid being cheated by unscrupulous suitors.

She describes her mission in this way on page 47 "It is my task sir, indeed my calling, to assist such ladies in ascertaining that the men who express a desire to marry them are not fortune hunters, opportunists or rakehells. I help them avoid the perils and pitfalls such women inevitably face."

Krentz's female characters are champions in the information game, but her male characters are also adept players. Some of the historical heroes employ Bow Street Runners (an early form of police) to gather needed 
information. Or they simply keep their ears to the ground. In her contemporary stories, the heroes often use computers to acquire information, and if the hero isn't a skilled computer user himself he knows someone who is, usually someone who owes him a favor. Several of the contemporary heroes have backgrounds involving intelligence work and have maintained contacts in the field who are more than happy to run checks on whoever or whatever needs checking. "Follow the money" is a frequent dictum. In several of her novels, for example, Deep Waters, locating financial records helps solve the mystery. In Sweet Fortune, the hero and heroine investigate a cult by posing as potential donors. While visiting the group's headquarters, the hero pulls computer printouts from the trash can in the men's room; printouts that help verify the group's unsavory mission. Obtaining the secrets of one's business rivals is a sure fire way to get ahead and stay ahead. It is rare in a Krentz novel for the hero not to be wealthy or an acknowledged success in his field; the men are usually self-made and self-employed. Thus, while she does not discuss library issues specifically, the importance of information -- having it, getting it, evaluating it, managing it, using it, and profiting from it, is a clear and present theme in her works.

\section{CONCLUSION}

It would seem the case for many of the librarian authors presented here, especially in their early works, to write what they know and what they know is librarianship and the significance of information in everyone's life real or fictional. Certainly librarians who write can present a more realistic view of life in a libraryland than those who only visit there occasionally. In cases where the librarians also have subject specialties those may take precedence (as with librarians who have historical training and write historical novels). Even so, those with an understanding of the importance of information and how to retrieve it effectively, may reflect that philosophy 
in their writings. The works studied in depth for this article have been primarily ones directed at women, although they often included male characters who were also skilled in librarianship or information gathering. However, it would be interesting to see if fiction written by librarians and aimed at a primarily male audience would also reflect these themes. The librarian author has, for the most part, slipped under the research radar. I hope that this article places these authors on the radar screen, and inspires others to conduct more study on this subject and to investigate other aspects of the librarian as author phenomenon.

\section{Bibliography}

Burgett, SW. (Fall 2001) "Back to the Library: Libraries and Librarians in Film: the Sequel," Kentucky Libraries," Kentucky Libraries 65 (4), 23-27.

Burns, G. (1998) Librarians in Fiction: A Critical Bibliography. Jefferson, NC: McFarland.

Chaintreau, A-M, Lemaitre, R. (1990). Droles de bibliotheques: le theme de la bibliotheque dans la litterature et le cinema. Paris: Editions du Cercle de la Librairie.

Chepesiuk, R. (1991, November) "In Pursuit of the Muse: Librarians Who Write." American Libraries 22, 88-91.

Cavanaugh, NJ. (1976). The Image of Librarians as Discussed in Professional Literature and Represented in Modern American and British novels, 1950-1975. MA thesis, University of Minnesota. 
Dowling, BD. (2001, March/April) "Be Willing to Break Your Own Heart: An Interview with Elizabeth McCracken," Public Libraries 40(2), 91-2.

Frylinck, JH, Oliver, J. (1990). Looks in Books: Images of Librarians in Literature, 1945-1990: a Bibliography. Perth: The Library, Curtin University of Technology, 1990.

King, WH. (1990). The Celluloid Librarian: the Portrayal of Librarians in Motion Pictures. MSLS thesis, University of North Carolina at Chapel Hill.

Krentz, JA. (Ed). (1992). Dangerous Men and Adventurous Women:

Romance Writers on the Appeal of Romance. Philadelphia: University of Pennsylvania Press.

Krentz, JA. (1997). Deep Waters. New York: Pocket Star.

Krentz, JA. (1992). Perfect Partner. New York: Pocket.

Krentz, JA. (2004). Private Eye. New York: Harlequin Reprint.

Krentz, JA. (1998). Sweet Fortune. New York: Pocket Reprint.

Long, LE. (1957) The Stereotyped Librarian as Portrayed in Modern American Belles-Lettres. MA thesis, Kent State University.

Monfredo, MG. (1995). Blackwater Spirits. New York: St. Martins Press. 
Monfredo, MG. (1999). Must the Maiden Die. New York: Berkley

Publishing Group.

Monfredo, MG. (1993). North Star Conspiracy. New York: St. Martins Press.

Monfredo, MG. (1992). Seneca Falls Inheritance. New York: Berkley Publishing Group.

Monfredo, MG. (1998). Stalking Horse. New York: Berkley Publishing Group.

Monfredo, MG. (1996). Through a Gold Eagle. New York: Berkley Publishing Group.

Nation, MA. (1956). The Librarian in the Short Story: an Analysis and Appraisal. MA thesis, University of Florida.

“Novel experience," (1994, Sept). LA Record 96, 482.

Poling, N. (2002, July 1). "A Testimony to the Non-Stereotypical Librarian," Information Outlook 6(7), 34.

Quick, A. (1998). Affair. New York: Bantam.

Quick, A. (2003). Don't Look Back. New York: Bantam.

Quick. A. (2004). Late for the Wedding. New York: Bantam. 
Quick, A. (1991). Scandal. New York: Bantam.

Quick. A. (2002). Slightly Shady. New York: Bantam.

Quick. A. (2005). Wait Until Midnight. New York: Berkley Publishing Group. 